\title{
Correlations of predatory whelks with intertidal prey at several scales of space and time
}

\author{
Peter G. Fairweather* \\ Institute of Marine Ecology and School of Biological Sciences, University of Sydney, NSW 2006, Australia
}

\begin{abstract}
Whelks and barnacles at 14 sites on a shore in New South Wales, Australia, were sampled during 5 yr to test for correlations through time between predators and their prey. These sites were classified as either 'favourable' or 'unfavourable' to whelks and experienced a range of abundances of whelks. Correlations varied widely with a variety of apparent time-lags, but the arrival of whelks usually resulted in declines of barnacles. Movements of groups of whelks and recolonization by settlement and recruitment of barnacle larvae greatly influenced these correlations. Furthermore whelk abundances were more variable at sites with the most whelks. Intensive sampling on 13 occasions over $105 \mathrm{mo}$ of $25 \mathrm{~m}^{2}$ of a different shore showed that 'tracking' of barnacles through time by whelks was stronger than correlations on a fine spatial scale at most instants in time. This temporal pattern, therefore, is not clear from examining many sites at once.
\end{abstract}

\section{INTRODUCTION}

Although observational studies of predator-prey relationships are common, there are relatively few long-term investigations of the natural fluctuations of predators and prey on seashores. Studies of terrestrial vertebrates, in contrast, have focussed on such predator-prey oscillations (Taylor 1984). Longer-term data may provide useful insights to the functional nature of predation (Morgan 1972, Paine 1974, 1986). For instance, Dayton (1971) observed a decline in abundance of predatory whelks in the second half of a 4 yr study which he attributed to mortality due to extremely cold weather. The subsequent effect on barnacle populations was to enhance successful recruitment and survival (Sebens \& Lewis 1985), but this was temporary at many sites, because of eventual predation by starfish (Dayton 1971).

In New South Wales, Australia, Fairweather et al. (1984), Moran (1985a, b), and Fairweather (1988a, b) analysed patterns of predation in terms of the foraging movements of the muricid whelk Morula marginalba Blainville, and experimentally tested the relationship between foraging, crevices and declines in barnacle densities. These authors did not, however, address the

\footnotetext{
- Present address: Centre for Environmental \& Urban Studies, Macquarie University, NSW 2109, Australia
}

question of whether there were long-term movements around the shore which might affect the representativeness of these situations. This article is concerned with such evidence and tests the possibility that the abundances of whelks and barnacles may be correlated over metres in space and over months or years in line. Any such correlations could be positive or negative and might be causally related (Frank \& Leggett 1985).

\section{METHODS}

Sampling medium-term abundances at several sites on one shore. The Cape Banks Marine Scientific Research Area $\left(34^{\circ} 0^{\prime} \mathrm{S}, 151^{\circ} 15^{\prime} \mathrm{E}\right)$ in New South Wales, Australia, has sandstone shores varying in aspect, slope and the biological communities present. During the early months of 1980 and 1981, I visited most parts of Cape Banks with the aim of categorizing the present status of populations of Morula marginalba, and gauging the realized 'favourability' of habitats for these whelks. These qualitative surveys suggested that somewhat less than $40 \%$ of apparently suitable habitat actually supported predators. As Moran (1985a) suggested, there are many locations on New South Wales seashores where whelks are chronically scarce (if present at all). From this I could subjectively categorize particular places as: (A) favourable habitat; or (B) 
unfavourable habitat. The former category included areas with and without whelks. It also included areas currently (i.e. in January 1981) without whelks, but known to have had whelks sometime in 1980 . The unfavourable category included places that were too exposed to waves (see Moran 1985a), had no prey (Moran 1985a), had no crevices or any other shelter in the vicinity (Fairweather et al. 1984), or consisted of large boulders in very sheltered sites (these had populations of the predatory crab Ozius truncatus $\mathrm{M}$. Edwards, which may exclude whelks from such places; Moran 1985a).

Within this habitat classification, I decided to monitor repeatedly some small $\left(1\right.$ to $6 \mathrm{~m}^{2}$ ) areas over several years to examine fluctuations in densities of predators and their prey. At Cape Banks, 11 areas of 'favourable' habitat, exhibiting a range of known histories of the density of whelks, and 5 areas of 'unfavourable' habitat, were chosen in early 1981. Most of these areas had been sampled in 1980 for other purposes and so could be categorized as to whether or not they had been invaded by noticeable populations of whelks during the previous year. These areas did not include extensive crevices (although places for whelks to shelter were found at the periphery of all favourable sites). All sites were at mid to high levels of the shore, and the main prey were barnacles (Tesseropora rosea [Krauss], plus Chamaesipho tasmanica [Spengler] at 2 sites), which constituted more than $85 \%$ of potential prey. The remainder were mainly molluscs such as large snails and chitons, which are only occasionally eaten (Fairweather et al. 1984). These sites were visited at irregular intervals (at least 4 times a year) until May 1984 , and the number of all barnacles in three $0.25 \mathrm{~m}^{2}$ quadrats were counted (or, less often, these were photographed and counts were later made from transparencies; this is known to be accurate, unpubl. data). The total number of whelks per site were also counted; these were almost all Morula marginalba with a few juvenile Thais orbita found in autumn.

Long-term fluctuations on part of one shore (longterm, small-spatial variation). The Nobbys Head $\left(32^{\circ} 50^{\prime} \mathrm{S}, 151^{\circ} 45^{\prime} \mathrm{E}\right)$ siltsone platform at Newcastle (north of Sychey) has been intermittently studied for 10 yr (Underwood et al. 1983, Caffey 1985). A $5 \times 5 \mathrm{~m}$ area at Nobbys Head was mapped in May 1979 (by M. J. Moran), and has been sampled 13 times over 8.75 yr. Moran took samples at 4 times during 1979 (erroneously stated as 1978 in Underwood et al. 1983), using a $20 \times 20$ grid of $0.065 \mathrm{~m}^{2}$ quadrats. At 9 times in 1980 to 1988 , I sampled with a contiguous, $10 \times 10$ grid of $0.25 \mathrm{~m}^{2}$ quadrats. In May 1983 , only 40 such quadrats (the same area as in Underwood et al. 1983) were sampled because time was limited. Moran counted Morula marginalba (and other animals) and estimated the percent coverage of Tesseropora rosea with a grid of 25 points. I counted both whelks and prey. For comparative purposes, I recalculated Moran's barnacle data using a regression of the number of $T$. rosea on the number of points contacted out of 25 [regression: number $=6.64$ (points out of 25) $-5.96, n=10, r=0.984 \mathrm{~J}$, and pooled the estimates for each of 4 smaller quadrats to correspond to my larger quadrats. Thus, the 1979 data are less precise than the later data.

\section{RESULTS}

\section{Medium-term monitoring of natural areas}

Of the 11 'favourable' sites chosen, 3 could be categorized (in early 1981) as having whelks (Fig. 1), 4 as having had some whelks in 1980 (Fig. 2), and 4 as not having whelks (Fig. 3). All subsequent changes in whelks occurred naturally. At one of the sites with whelks, all whelks left soon after monitoring was begun but whelks moved in again after 6 mo (Fig. 1a). Populations of whelks persisted at the other sites (Fig. $1 b, c)$. Densities of barnacles were small in relation to other sites, and in 2 cases declined to zero during the monitoring.

In areas that during 1981 were recovering from invasions of whelks that had occurred in 1980, barnacle

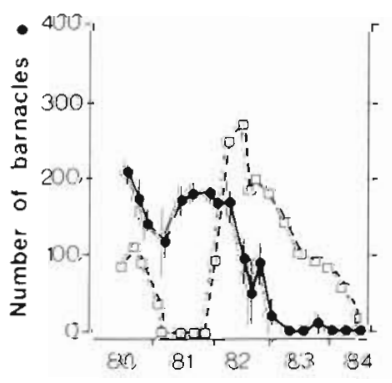

B

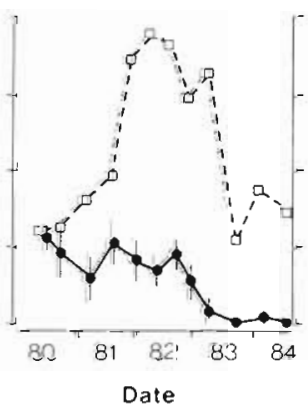

C

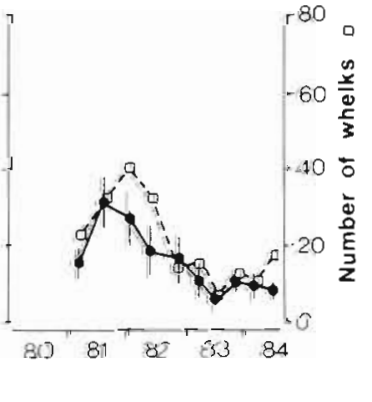

Fig. 1 Morula marginalba and Tesseropora rosea. Densities of whelks and of barnacles in 3 areas designated as 'favourable' habitat for whelks and where they were present in 1980 and 1981. Means ( \pm SE) of barnacles per $0.25 \mathrm{~m}^{2}$ (left-hand axis) and numbers of whelks per $\mathrm{m}^{2}$ (right-hand axis); the latter were calculated from counts of whelks per site divided by the area of the site and thus have no error estimates 


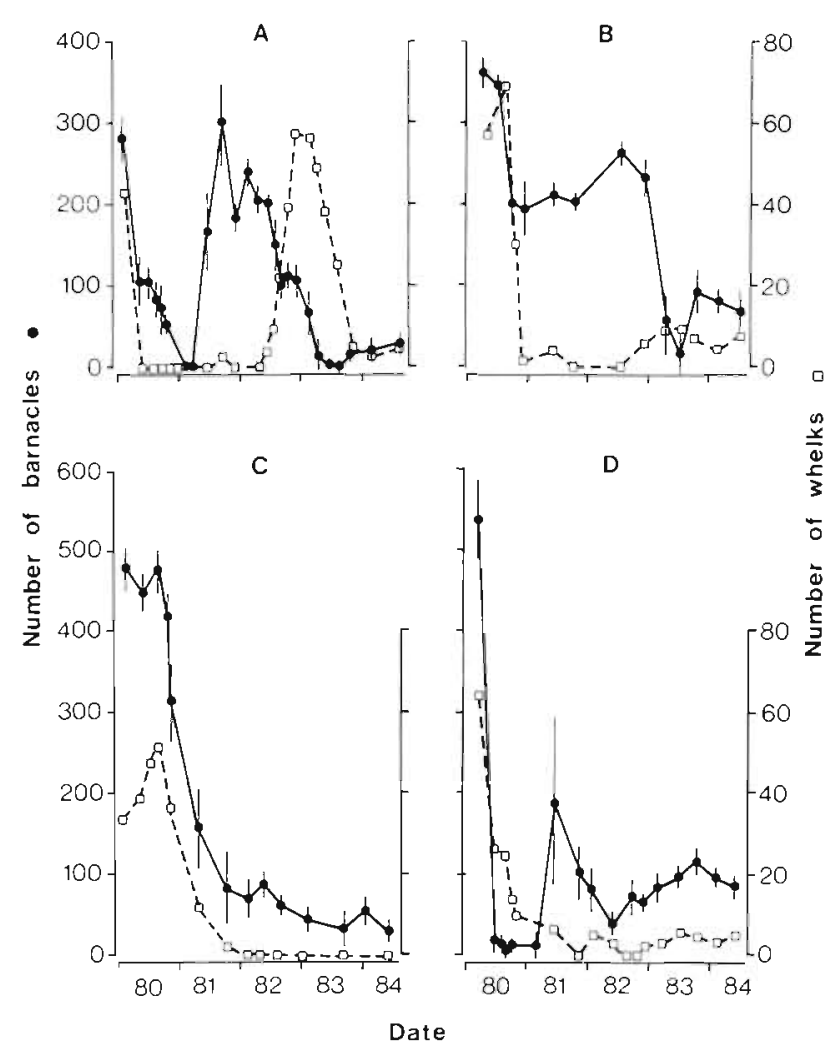

Fig. 2. Morula marginalba and Tesseropora rosea. Densities of whelks and of barnacles in 4 areas 'favourable' to whelks where they were present in 1980 but not in early 1981. Legend as in Fig. 1

densities were also smaller in the second year of observation (Fig. 2). Densities increased via recruitment during 1981, except for 1 area (Fig. 2c). This was dominated by Chamaesipho tasmanica; no subsequent recruitment occurred, and the decline of barnacles continued. In the other 3 cases, whelks reinvaded the areas (Fig. 2a, b, d) and in 1 area reached greater densities than during 1980. Barnacle densities then declined again, except where an apparently static level of few whelks and small densities of barnacles persisted over 2 yr until the end of sampling (Figs. $1 c$ and $2 d$ ).
Among 'favourable' areas initially lacking whelks, 3 were invaded during the next 3 yr (Fig. 3a, b, c). These invasions coincided with dramatic reductions in the density of barnacles, whereas the single uninvaded area maintained a greater density of Tesseropora rosea.
A

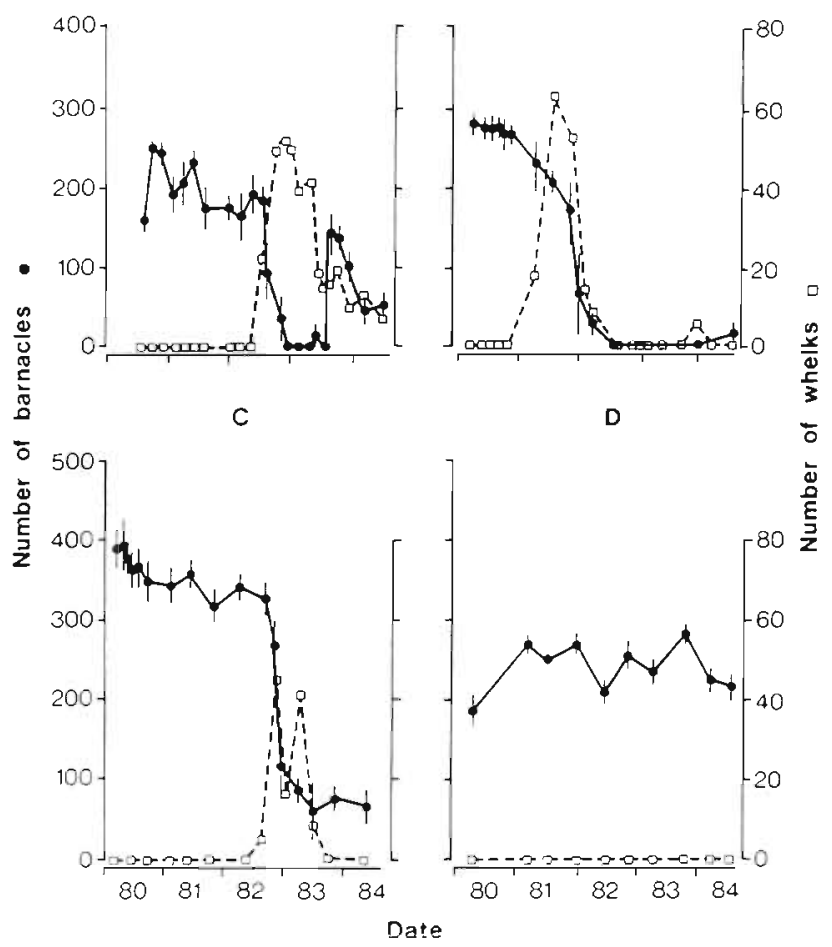

Fig. 3. Morula marginalba and Tesseropora rosea. Densities of whelks and of barnacles in 4 areas 'favourable' to whelks that lacked them in 1980 and early 1981. Legend as in Fig. 1

In 2 cases the whelks left after 1 to $1.5 \mathrm{yr}$ (Fig. 3b, c), but in the third case persisted longer at reduced densities (Fig. 3a).

Of the 5 'unfavourable' sites chosen, 1 could be categorized as being too wave-exposed (Fig. 4a), 2 as lacking crevices (Fig. 4b, c), 1 as lacking prey, and 1 as
A

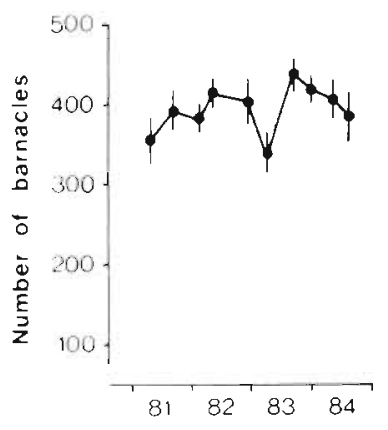

B

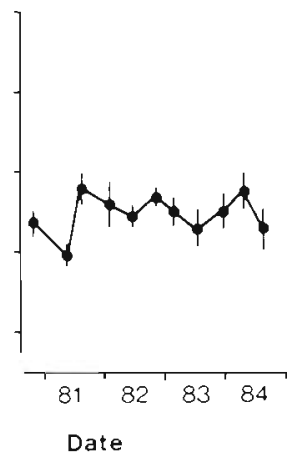

C
Fig. 4. Tesseropora rosea. Densities of barnacles in 3 areas designated as 'unfavourable' to whelks. Means ( $\pm \mathrm{SE}$ ) 
being too wave-exposed in addition to lacking potential prey. No whelks were observed at these sites in 3 yr. These last 2 sites are not shown in Fig. 4 , because neither whelks nor barnacles were seen there in $3 \mathrm{yr}$. One was in the most sheltered part of Cape Banks near a field of small boulders (McGuinness 1984), populated by large specimens of the gastropod Nerita atramentosa (Reeve) ( $20 \mathrm{~mm}$ in size, 240 per $\mathrm{m}^{2}$ ), an ephemeral covering of ulvoid algae, and the perennial red alga Hildenbrandia prototypus Nardo. Under similar conditions on an adjacent site, Underwood (1975 and pers. comm.) and Denley (1981) found no settlement of Tesseropora rosea from 1973 to 1984 . The second site was on the Outside at the very end of Cape Banks. At this extremely wave-exposed site, encrusting coralline algae, amphipods and some large chitons lived under a thick, persistent cover of ulvoid algae.

At the other 3 'unfavourable' sites, barnacles were consistently present as dense, persistent populations of large individuals (>9 $\mathrm{mm}$ aperture lengths). These populations were not as variable as those on the other 11 sites (Fig. 4; Fairweather 1988c). Correlations were also calculated between the densities of whelks and barnacles at each time where both were sampled. These (Table 1) ranged from significantly positive to significantly negative, which suggests no general 'tracking' of barnacles by whelks. This is reinforced by the large range of apparent time lags between abundances of whelks and barnacles observed in these data (Table 1).

\section{Long-term, small-spatial-scale changes}

Using the data from Nobbys Head, I calculated simple correlations between abundances of Morula marginalba and Tesseropora rosea in the quadrats, for each time. Most $(62 \%)$ of these correlations were not significant (Table 2). The only positive, significant correlation occurred in 1979 when both whelks and prey were common (Moran initiated this data collection to examine spatial relationships between predation over time and barnacle density). The significant, negative correlations occurred in the last 4 samples. Many whelks were seen eating these barnacles, so the negative relation may be a direct effect of predation. Since 1982, nearly all barnacles present were juveniles from the previous settlement (probably in June), and whelks were eating many of them. During the middle years of sampling, the correlations were particularly weak, probably because at least one of the species was very sparse at each time (Table 2). There was also a strong positive correlation between the mean densities of whelks and barnacles, using each sampling time as an independent replicate $(r=0.957, n=13, p<0.01)$. Other aspects of this sampling will be dealt with elsewhere (Moran \& Fairweather unpubl.).

\section{DISCUSSION}

At all sites where present whelks were observed feeding on barnacles and thus seem to be a major cause of mortality. Increases in numbers of barnacles occurred mainly during autumn and winter (the settling season; Caffey 1985), while whelks invaded mainly during the warmer months. This invasion represents increased activity of large whelks (12 to $18 \mathrm{~mm},>2 \mathrm{yr}$ old; Moran 1985a), rather than recruitment. Declines in numbers of Morula marginalba were probably not due to mortality because almost all of those that I had marked could be found some distance away in sub-

Table 1. Morula marginalba and Tesseropora rosea. Temporal correlations between densities of whelks and barnacles at each site at Cape Banks, calculated using data from times when both species were sampled (hence $n$ may differ from the number of points in the figures cited). Lags are estimated from inspection of the relevant figure; no formal analysis of lagged correlations was attempted due to the irregular intervals between samples. No correlations were possible for sites shown in Fig. $3 \mathrm{~d}$ and $4 a, b, c$ because no whelks were seen on them (their site areas were $2.15,3.2,3.1$ and $3.0 \mathrm{~m}^{2}$, respectively). In the regressions of whelk density on barnacle density, the value of the intercept a may be interpreted as the number of whelks that stay when no barnacles are left

\begin{tabular}{|c|c|c|c|c|c|c|c|}
\hline \multirow{2}{*}{$\begin{array}{l}\text { Fig. } \\
\text { No. }\end{array}$} & \multirow{2}{*}{$\begin{array}{c}\text { Site area } \\
\qquad\left(\mathrm{m}^{2}\right)\end{array}$} & \multicolumn{4}{|c|}{ Correlation } & \multicolumn{2}{|c|}{ Regression } \\
\hline & & $r$ & $n$ & Significance & $\operatorname{Lag}(m o)$ & $B$ & $a$ \\
\hline $1 \mathrm{a}$ & 2.76 & -0.578 & 18 & $p<0.02$ & $1-3$ & -0.123 & 32.2 \\
\hline $1 b$ & 2.34 & 0.185 & 12 & NS & $1-2$ & 0.092 & 40.5 \\
\hline $1 c$ & 1.78 & 087 & 10 & $p<0.01$ & $1-3$ & 0.225 & 3.4 \\
\hline $2 a$ & 2.39 & -0.298 & 26 & NS & $3-12$ & -0.07 & 20.6 \\
\hline $2 b$ & 3.52 & 0.624 & 13 & $p<0.02$ & $?$ & 0.1 .27 & -7.6 \\
\hline $2 \mathrm{C}$ & 5.29 & 0.967 & 13 & $p<0.001$ & 0 & 0.099 & -5.1 \\
\hline $2 d$ & 4.31 & 0.65 & 17 & $p<0.01$ & 6 & 0.084 & 5.2 \\
\hline $3 a$ & 4.86 & -0.593 & 23 & $p<0.01$ & $8-12$ & -0.135 & 34.3 \\
\hline $3 b$ & 1.27 & -0.142 & 19 & NS & $\geq 12$ & -0.07 & 29.5 \\
\hline $3 c$ & 2.87 & -0.52 & 17 & $p<0.05$ & 3 & -0.04 & 15.6 \\
\hline
\end{tabular}


Table 2. Morula marginalba and Tesseropora rosea. Correlations between the abundances of whelks and barnacles in a $25 \mathrm{~m}^{2}$ area at Nobbys Head, Newcastle. Total number of quadrats was 100 (except May 1983, when the total was 40); only quadrats with at least one of the species present were included in calculations of correlations (see $n$ ). Note that in Table 3 of Underwood et al. (1983). 1979 data for T. rosea was incorrectly labelled as 1978

\begin{tabular}{|c|c|c|c|c|c|c|}
\hline \multirow[t]{2}{*}{ Year } & \multirow[t]{2}{*}{ Month } & \multicolumn{2}{|c|}{ Mean density per $0.25 \mathrm{~m}^{2}$} & \multicolumn{2}{|c|}{ Correlation } & \multirow[t]{2}{*}{ Significance } \\
\hline & & M. marginalba & $T$ rosea & $r$ & $n$ & \\
\hline \multirow[t]{4}{*}{1979} & May & 22.0 & 547.5 & 0.12 & 92 & NS \\
\hline & Jul & 17.7 & 415.3 & -0.09 & 90 & NS \\
\hline & Sep & 9.4 & 242.8 & 0.28 & 76 & $p<0.02$ \\
\hline & Dec & 2.1 & 32.6 & 0.25 & 32 & NS \\
\hline 1980 & Nov & 7.4 & 1.1 & 0.07 & 84 & NS \\
\hline 1982 & May & 3.5 & 0.02 & -0.02 & 73 & NS \\
\hline \multirow[t]{2}{*}{1983} & May & 4.4 & 68.6 & 0.01 & 40 & NS \\
\hline & Aug & 4.1 & 55.5 & -0.09 & 100 & NS \\
\hline \multirow[t]{2}{*}{1984} & Mar & 1.2 & 0.2 & -0.06 & 44 & NS \\
\hline & Aug & 2.3 & 10.7 & -0.46 & 99 & $p<0.01$ \\
\hline 1986 & Feb & 0.8 & 31.5 & -0.41 & 100 & $p<0.01$ \\
\hline 1987 & Feb & 5.9 & 54.5 & -0.34 & 99 & $p<0.01$ \\
\hline 1988 & Feb & 1.9 & 1.8 & -0.25 & 72 & $p<0.025$ \\
\hline
\end{tabular}

sequent aggregations (Fairweather 1988b). Such vagaries seem typical of the unpredictable movements of 'hordes' of M. marginalba described by Moran (1985b), and invading whelks are capable of eliminating populations of prey such as barnacles. Suitable areas may, however, be free of predation for periods of months (Fig. 2), or years (Fig. 3), so that predation may be localized and intermittent in some situations. This is similar to the fluctuations described by Denley (1981), Creese (1982), Underwood et al. (1983) and Caffey (1985). The cases where barnacles persisted in the absence of whelks cannot justifiably be considered an alternate stable state (Connell \& Sousa 1983), because of the short time-span of these observations compared to the potential longevity of these animals (Denley 1981, Moran 1985a).

From the long-term, correlative evidence, whelks seem to contribute to fluctuations in densities of barnacles at medium spatial scales (see also Fairweather et al. 1984). Although whelks are capable of moving away from sites, declines in barnacles must result from mortality (unlike the case given in Frank \& Leggett 1985). There also appeared to be less variation in barnacle densities at sites without whelks (Fairweather 1988c). The movements of large numbers of whelks result in an infrequent, largely unpredictable feature of this predator-prey system. Patchiness of prey is directly related to predation clearing small areas in mature stands of prey (as in Dayton 1971). These patterns of invasion by whelks and recolonization by prey can also be considered analogous to Caswell's (1978) mosaic model of predation. The independent actions of different hordes of such predators spread over several sites (Caswell's cells) may act together at a larger scale enhancing the mosaic nature of the community, determining succession in patches and promoting global diversity of various states in the community (Dayton 1971, Caswell 1978).

These sorts of data can provide a context (including relatively rare events; Sebens \& Lewis 1985) within which to place observations over shorter periods (Wiens 1983) and to interpret experimental results. Connell (1974) pointed out that experimental field studies, testing specific hypotheses at small scales of time and space, can identify the range of potential interactions among members of ecological assemblages. Observational field studies of populational dynamics (e.g. this study) put such suites of potential interactions into perspective. This can be done by specifying how often each set of 'starting conditions' is encountered, thus indicating which situations are more likely to occur than others. For example, the effects of crevices are suggested in this study by the variations in results between the situations with crevices (Figs. 1 to 3) and sites without crevices (Fig. 4). Corroboration of this causal suggestion comes from experiments with crevices (Fairweather et al. 1984, Fairweather 1988a, b). This effect and the dramatic impact of the roving hordes of whelks await incorporation in a model of foraging by whelks (Moran \& Fairweather unpubl.). The next task is to attach realistic probabilities to these different outcomes and influences identified by experiment; these are derived from looking at many field cases that reflect natural variability.

Monitoring small sites at Cape Banks indicated that localized coupling through time of predators and prey in this community is very loose. This conclusion could only be reached, however, by directly documenting 
cycles in time using repeated sampling through time of both predators and prey (Watt 1947). It is not good enough to find several locations in space that are presumed to represent different states in a theoretical cycle (e.g. Wharton \& Mann 1979, Bradbury et al. 1985). Such a procedure assumes that the so-called ergodic hypothesis (i.e. that space can be substituted for time; Kent 1987) is justified by more than expediency. It is very difficult to confidently infer causal relationships from correlations of consumers and producers (Frank \& Leggett 1985, Pepin 1987), although predator-prey cycles were first highlighted in the Lotka-Volterra models. For example, Hartnoll \& Hawkins (1985) presented a poor correlation between whelks and barnacles, and therefore linked fluctuations of barnacles to another factor (algal overgrowth).

In contrast, strong positive correlations would imply possible numerical responses of predators. The strongest positive signals in these data are the tracking of densities through time rather than space (where few small-scale correlations were significant; Table 2). Similar evidence of tracking was found by Katz (1985) and Moran (1985a). These temporal patterns were not apparent from examining any number of sites at one or only a few instants in time. Thus is the value of longterm records of predator-prey relationships.

Acknowledgements. This study forms part of a $\mathrm{Ph}$. D project at the University of Sydney done with the support of a Commonwealth Postgraduate Research Award. I thank Drs A. J. Underwood, M. J. Moran, C. H. Peterson, J. H. Connell, R. T Paine and others for discussions, and Drs Underwood and M. J. Kingsford and 3 referees for comment on the manuscript. E. Bragg drew the figures and assisted with fieldwork, as did V. Nelson, H. Caffey, K. Jenkins, J. Warren and R. Hinchliffe. Dr M. J. Moran kindly gave me the use of some unpublished data.

\section{LITERATURE CITED}

Bradbury, R. H., Hammond, L. S., Moran, P. J, Rejchelt, R. E. (1985). Coral reef communities and the crown-of-thorns starfish: evidence for qualitatively stable cycles. J. theor. Biol. 113: 69-80

Caffey, H. M. (1985). Spatial \& temporal variation in settlement \& recruitment of intertidal barnacles. Ecol. Monogr. 55: $313-332$

Caswell, H. (1978). Predator-mediated coexistence: a nonequilibrium model. Am. Nat. 112: 127-154

Connell, J. H. (1974). Field experiments in marine ecology. In: Mariscal, R. (ed.) Experimental marine biology. Academic Press, New York, p. 21-54

Connell, J. H., Sousa, W. P. (1983). On the evidence needed to judge ecological stability or persistence. Am. Nat. 121. $789-824$

Creese, R. G. (1982). Distribution and abundance of the acmaeid limpet Patelloida latistrigata, and its interaction with barnacles. Oecologia (Berl.) 52: 85-96

Dayton, P. K. (1971). Competition, disturbance and commun- ity organization: the provision and subsequent utilization of space in a rocky intertidal community. Ecol. Monogr. 41 351-389

Denley, E. J. (1981). The ecology of the intertidal barnacle Tesseropora rosea. Thesis, University of Sydney

Fairweather, P. G. (1988a). Predation causes haloes of bare space amongst prey on seashores in New South Wales. Aust. J. Ecol. 13: in press

Fairweather, P. G. (1988b). Movement of intertidal whelks in relation to their prey and shelter. Mar. Biol. (in press)

Fairweather, P. G. (1988c). Predation can alter variance/mean relationships in the abundance of prey on seashores. Oikos 53: in press

Fairweather, P. G., Underwood, A. J, Moran, M. J. (1984). Preliminary investigations of predation by the whelk Morula marginalba. Mar. Ecol. Prog. Ser. 17: 143-156

Frank, K. T., Leggett, W. C. (1985). Reciprocal oscillations in densities of larval fish and potential predators: a reflection of present or past predation? Can. J. Fish. Aquat. Sci. 42: $1841-1849$

Hartnoll, R. G., Hawkins, S. J. (1985). Patchiness and fluctuations on moderately exposed rocky shores. Ophelia 24: $53-63$

Katz, C. H. (1985). A nonequilibrium marine predator-prey interaction. Ecology 66: 1426-1438

Kent, M. (1987). Island biogeography and habitat conservation. Prog. Phys. Geog. 11: 91-102

McGuinness, K. A. (1984). Species-area relation of communities on intertidal boulders: testing the null hypothesis. J. Biogeog. 11: 439-456

Moran, M. J. (1985a). Distribution and dispersion of the predatory intertidal gastropod Morula marginalba. Mar Ecol. Prog. Ser. 22: 41-52

Moran, M. J. (1985b). The timing and significance of sheltering and foraging behaviour of the predatory intertidal gastropod Morula marginalba (Muricidae). J. exp. mar. Biol. Ecol. 93: 103-114

Morgan, P. R. (1972). The influence of prey availability on the distribution and predatory of Nucella lapillus (L.). J. Anim. Ecol. 41: 257-272

Paine, R. T (1974). Intertidal community structure: experimental studies on the relationship between a dominant competitor and its principal predator Oecologia 15: $93-120$

Paine, R. T (1986). Benthic community-water column coupling during the 1982-1983 El Niño: are community changes at high latitudes attributable to cause or coincidence? Limnol. Oceanogr. 31: 351-360

Pepin, P. (1987). Trophic relationships in freshwater pelagic ecosystems: a question of averages and sampling error? Can. J. Fish. Aquat. Sci. 44: 1096-1097

Sebens, K. P., Lewis, J. R. (1985). Rare events and population structure of the barnacle Semibalanus cariosus. J. exp. mar Biol. Ecol. 87: 55-65

Taylor, R. J. (1984). Predation. Chapman \& Hall, London

Underwood, A. J. (1975). Comparative studies on the biology of Nerita atramentosa Reeve, Bembicium nanum (Lamarck) and Cellana tramoserica (Sowerby) (Gastropoda: Prosobranchia) in southeastern Australia. J. exp. mar. Biol. Ecol. 19: 153-172

Underwood, A. J., Denley, E. J., Moran, M. J (1983). Experimental analyses of the structure and dynamics of midshore rocky intertidal communities in New South Wales. Oecologia (Berl.) 56: 202-219

Watt, A. S. (1947). Pattern and process in the plant community. J. Ecol. 35: 1-22

Wharton, W. G., Mann, K. H. (1979). Relationship between 
destructive grazing by the sea urchin, Strongylocentrotus droebachensis, and the abundance of American lobster, Homarus americanus, on the Atlantic coast of Nova Scotia. Can. J. Fish. aquat. Sci. 38: 1339-1349
Wiens, J. A. (1983). Avian community ecology: an iconoclastic view. In: Brush, G., Clark, D. (eds.) Perspectives in ornithology. Cambridge University Press, Cambridge, p. 355-403

This article was presented by Dr R. N. Hughes; it was accepted for printing on April 27, 1988 